\title{
O ensino da dermatologia nos finais de semana Weekend dermatology courses
}

A flagrante e crescente procura da especialização em dermatologia pode ser explicada, pelo menos em parte, por breve análise histórica. Até o início da década de 1970, as quatro grandes áreas médicas (clínica médica, pediatria, ginecologia e cirurgia) reinavam absolutas entre as preferências dos recém-formados. Reflexos, talvez, de uma era romântica - ingênua e ultrapassada para alguns da medicina sacerdócio.

A partir de então sucederam-se como áreas principais de interesse a cirurgia plástica, prenúncio de uma era marcada pela busca desmedida de beleza e sua elevação a objetivo maior da vida, o diagnóstico por imagem, reflexo do avanço tecnológico representado pelo advento consecutivo da ultra-sonografia, tomografia computadorizada e ressonância magnética, e a oftalmologia, pela incorporação de procedimentos cirúrgicos.

Mais recentemente, a endocrinologia e a dermatologia tornaram-se as especialidades da moda. Tal fato poderia ser auspicioso, caso refletisse o progresso dessas áreas e a ampliação dos horizontes de pesquisa. No que diz respeito à nossa especialidade, não há muito a comemorar. Sem subterfúgios ou meias palavras, as razões são fundamental, se não exclusivamente, de ordem financeira. Em cenário no qual o cliente particular representa uma espécie em risco de extinção e o domínio dos convênios determina remuneração indigna, os procedimentos cosméticos surgem como alternativa de baixa complexidade e garantido retorno financeiro.

Além das distorções na imagem da especialidade e de seus praticantes, a procura frenética da dermatologia deu origem à espúria indústria dos cursos de final de semana. Sob o argumento, extremamente palatável aos interessados, de oferecer educação médica continuada e possibilitar a difusão do conhecimento aos que não conseguiram acesso aos cursos formais, tentam disfarçar sua inequívoca vocação comercial empregando neologismos (taxas e custos recebem agora o pomposo nome de "investimento") e acenando com a possibilidade, irreal, de capacitar os egressos a prestar exame de título de especialista da AMB/SBD.

Os Anais Brasileiros de Dermatologia, alinhados às diretrizes educacionais de nossa entidade científica, reiteram a relevância, seriedade de propósitos e qualidade da Educação Médica Continuada em Dermatologia conduzida pela SBD por intermédio de seus órgãos, serviços credenciados, regionais e departamentos especializados. Lamentam, por outro lado, a concessão de créditos pela Comissão Nacional de Acreditação (CFM/AMB) a cursos que receberam parecer contrário da SBD. $\square$

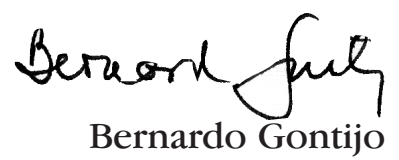

Editor Científico dos Anais Brasileiros de Dermatologia
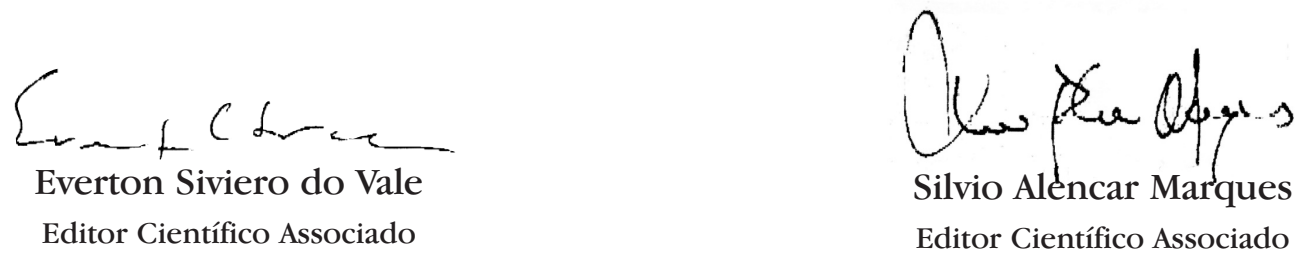

Como citar este artigo / How to cite this article: Gontijo B, Vale ECS, Marques SA. O ensino da dermatologia nos fins de semana. An Bras Dermatol. 2008;83(3):185. 